\title{
FIRST NATIONS LAND MANAGEMENT ACT AND THIRD PARTY INTERESTS
}

\author{
THOMAS ISAAC
}

In 1999 the Government of Canada enacted the First Nations Land Management Act, which is designed to provide first Nations with increased control and authority over land management on Indian reserve land and to replace related provisions in the Indian Act. This article addresses concerns regarding third party interests and licences under this new Act, in that such interests may be less secure than under the old land management regime. The author then outlines some potential remedies to the existing ambiguities found in the new land management regime as a way to provide practical suggestions for First Nations to fully develop and utilize their First Nation land.
En 1999. le Gouvernement du Canada a adopié la Loi sur la gestion des terres des premicres nations. dont le but consiste a fournir aux Premicres nations un plus grand confrole et une plus grande autorité sur ta gestion des terres des rëserves indiennes el à remplacer les dispositions afferentes de la Loi sur les Indiens. Cet article aborde les préoccupations relatives aux intèrèts de tiers et des permis accordès en verm de la nouvelle loi, en ce sens que lesdits intéréts peuvent étre moins sürs que sous lancien régime de gestion. L. 'auteur énonce ensuite cerlains remèdes éventuels aux ambiguliés existantes trouvées dans le nouveau régime pour donmer des suggestion.s pratiques aux Premières nations, da savoir de pleinement développer et uriliser leurs ferres.

\section{TABle OF CONTENTS}

I. INTRODUCTION ............................... 1047

II. FIRST NATIONS LAND MANAGEMENT ACT ............... 1048

A. BACKGROUND ............................ 1048

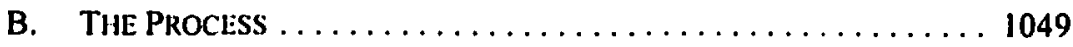

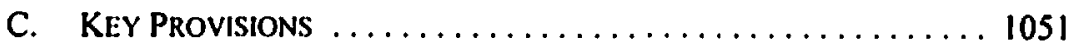

D. Case Law ............................... 1051

III. THE FNLMA AND ITS POTENTIAL EFFECT ON

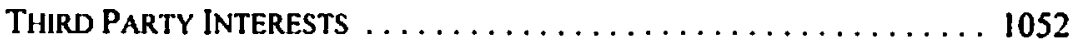

A. EXISTING INTERESTS AND LICENCES $\ldots \ldots \ldots \ldots \ldots \ldots \ldots, 1052$

B. EXPROPRIATION .......................... 1053

C. GOVERNANCE AND TAXATION AUTHORITY ........... 1054

D. Conflict of Laws ....................... 1055

E. OPTIONS FOR TIIIRD PARTY INTERESTS IN

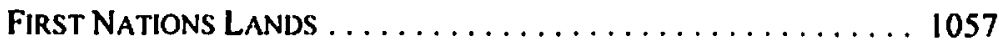

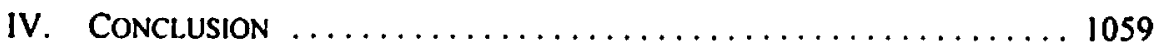

\section{INTRODUCTION}

Ambiguity has always surrounded the ability of third parties' to be granted interests in Indian reserve land ("First Nation land") ${ }^{2}$ and the security that could attach to such interests

MeCarthy Tétrault LI.P, Vancouver, Betitish Columbia. The author wishes to acknowledge the assıstance of Sean Rowell in the preparation of this article.

1 The term "third party" is used to represent all those interests that are not "First Nation" secking the ust: and enjoyment of Indian reserve lands, including utility companies (e.g. telephone, electric, pipeline). highway departments and private developers.

: The phrase "First Nation land," as used in this article, refers to "Fitst Nation land" as defined in s. 2(1) of the FNL.MA. infro note 4, and means Indian reserve land to which a land code applies 
under the Indian Act. ${ }^{3}$ Indeed, many developments have been frustrated by the inability of lenders and project developers, for example, to obtain adequate security of tenure or security of assets on First Nation land. Additionally, many First Nations have been frustrated by their inability to provide adequate security of tenure to non-First Nation entities seeking to use or develop First Nation land. In 1999, Parliament enacted the First Nations Land Management $\mathrm{Act},{ }^{4}$ which is designed to provide First Nations with increased control and authority over land management on their Indian reserve land and to replace related provisions of the Indian Act.

The ambiguity that existed under the Indian $A c t$ land management regime appears to have been carried forward and even exasperated under the $F N L M A$ regime due to a lack of adequate safeguards for third party interests (existing and future) and by not providing First Nations with clearly set out mechanisms by which such certainty and stability can be secured. For third parties, such as utility companies seeking access to, or interests in, First Nation land, the FNLMA represents a significant and fundamental change with respect to the legal nature of tenures traditionally relied upon by such third parties on First Nation land, such that the tenures issued under the FNLMA regime may be considerably less secure and stable than those issued under the former Indian ACt regime. While the FNLMA presently only applies to a relatively small number of First Nations," its broader application is likely to be inevitable as more First Nations are added to those able to come under the FNI.MA umbrella.

This article discusses the FNLMA and third party interests, how such third party interests. such as highway, utility and pipeline rights-of-way and easements and project developers generally, may be less secure under the FNLMA regime and how such interests may, with the appropriate amendments made to the FNLMA, be protected under this new legal regime. Additionally, by outlining potential remedies to some of the ambiguities in the FNLMA, the article seeks to provide practical suggestions to First Nations so as to allow them, where they desire, to fully develop and utilize their First Nation land.

\section{FIRST NATIONS LAND MANAGEMENTACT}

\section{A. BACKGROUND}

The FNLMA ratified and brought into effect the Framework Agreement on First Nations: Land Management.. The Framework Agreement, signed by the Government of Canada (Canada) and 14 First Nations in 1996, allows First Nations to opt out of the land administration sections of the Indian $A c t$ and establish their own land management regimes through the enactment of a land code. The FNLMA was required under the Framework Agreement for two purposes: (a) to ratify the Framework Agreement, and (b) to implement those clauses of the Framework Agreement that affect third parties or other federal laws, or

R.S.C. 1985 , c. I.5.

S.C. 1999. c. 24 [FNLMA].

As of writing. 36 First Nations are listed in the FNLMA's schedule that lists those First Nations cligible to take advantage of the FNLMA regime.

Online: Framework Agreement on First Nations Land Management <www.fafnlm.com/L.AB.NSF/

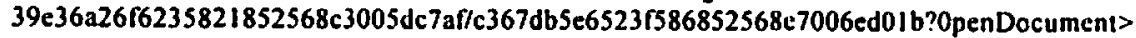

[Frameirork Agreement]. 
that are considered important enough to be repeated in the legislation.' In March 2002, the FNLMA regime was opened up to other First Nations."

Much of the FNLMA relates to the process by which First Nations can establish a land code and thereby remove their reserve lands from the control of the Minister of Indian Affairs and Northern Development (Minister), under the authority of the Indian Act. The FNLMA does not affect the title to First Nation land, with such lands continuing to be held by the federal Crown and "reserved" for the use and benefit of First Nations.

A land code, duly enacted by a First Nation pursuant to the $F N L M A$, will have the force of law and be recognized by the courts." Under the FNLMA and pursuant to its land code. a First Nation has the authority to manage First Nation land and may exercise the rights and privileges held by other land owners. Such First Nations are also granted the capacity necessary to exercise powers such as: acquiring and holding real and personal property: entering into contracts; borrowing money; expending and investing money; and becoming a party to legal proceedings. With the enactment of a land code, revenue moneys of a First Nation will no longer be transferred through Canada but will flow directly to the First Nation. First Nations under the FNLMA also have law-making powers covering a broad array of matters related to First Nation land, including the granting of interests in land, land use. environmental protection and the possession of matrimonial property. The power to enforce, and prosecute under, First Nation laws is also included in the $F N L M A$, and a separate register is authorized to record interests granted by First Nations under their respective land codes.

Under the FNLMA, First Nations possess the authority to expropriate certain interests in land for community works or other First Nation community purposes. The right of Canada to expropriate First Nation land is limited to justifiable circumstances and necessary for a federal public purpose that serves the national interest. As a result, under the FNLMA, First Nation land is immune from provincial expropriation.

\section{B. THE Process}

In order to establish a land management regime and be removed from the land provisions of the Indian Act, a First Nation must adopt a land code applicable to all First Nation land. The land code will set out rules and procedures for:

(a) the use and occupancy of First Nation's land, including licences, leases and allotments under s. 20(1) of the Indian $A c t ;{ }^{\prime 0}$

(b) the transfer of land interests and the revenues from natural resources obtained from reserve land;

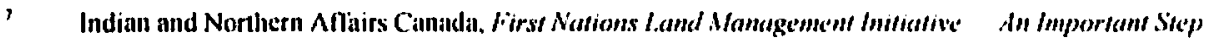
Tourards Self-Governance for First Nations (20 Marcli 2002), online: Indiant and Northern Artairs Canada <www.ainc-inac.ge.civ/nr/prs/j-a2002/2-02125.t. .html>.

lbid.

FNLMA, supra note 4, s. 15(1).

10 Subsection 20(1) of the Indian Act, supra note 3, slates that "No lindian is lawfully in possession of land in a reserve unless, with the approval of the Minister, possession of the land has been allotted to him by the council of the band." 
(c) requirements for accountability to First Nation members for land management and moneys derived from reserve land;

(d) community consultation processes for the development of rules respecting matrimonial property issues, use, occupation and possession of First Nation land and the division of interests in First Nation land;

(e) publication of First Nation laws;

(f) conflicts of interest in the management of First Nation land;

(g) the establishment of a forum for the resolution of disputes in relation to interests in First Nation land;

(h) granting or expropriating interests in First Nation land;

(i) delegation by the council of its authority to manage land;

(j) approvals of an exchange of First Nation land; and

(k) amending the land code."

The adoption of a land code involves four steps: an individual agreement, verification, comınunity approval and certification. First, the First Nation must enter into an individual agreement with the Minister describing: the land; the terms of the transfer of administration of the land; the interests and licenses operating on the land at the date of transfer; and the environmental assessment process that will apply to projects on that land until the First Nation enacts its own assessment bylaws. ${ }^{2}$ The First Nation then must submit the proposed land code to a "verifier" who is jointly appointed by the First Nation and the Minister. The verifier will determine whether the proposed land code, the proposed approval process and the individual agreement are in accordance with both the Framework Agreement and the FNLMA. ${ }^{13}$ Upon verification of the proposed code, the First Nation's council may submit the proposed land code and individual agreement to its members for approval. The council is required to notify third parties who have an interest in the land subject to the proposed land code within a reasonable time before the vote. ${ }^{14}$ If a First Nation approves the land code and individual agreement, the verifier must certify the validity of the code. Once a land code is certified by the verifier, it comes into force on the day of certification, or an alternate date specified in the land code. ${ }^{\text {is }}$

On the coming into force of the land code, a First Nation will have the power to enact laws with respect to interests in, and in relation to, First Nation land. The First Nation will exercise the rights, powers and privileges of an owner in relation to the land including granting interests and licences relating to, and receiving all moneys acquired from, such land. The First Nation also becomes responsible for managing the lands, including all natural resources, development, conservation, protection and use and possession of the land. They will also possess the power to control or prohibit land use and development through zoning and subdivision control. The First Nation will be responsible for the provision of local services and the imposition of equitable user charges for such services. They will also be responsible for 
environmental assessment and protection and be empowered to enact laws on any matter arising out of, or ancillary to, such powers. ${ }^{16}$

\title{
C. Key Provisions
}

Upon coming into force, a land code has the force of law and the following provisions of the FNLMA become relevant:

(a) No interest in, or license in relation to, the First Nation land may be granted or acquired except in accordance with the land code. ${ }^{17}$

(b) Revenues from an interest in the First Nation land are transferred to the First Nation. ${ }^{18}$

(c) The council of the First Nation has legislative powers in relation to the First Nation land. ${ }^{19}$

(d) Canada will not be liable for the acts or omissions by the First Nation in relation to the First Nation land after the land code comes into effect. ${ }^{20}$

(e) The land management provisions of the Indian ACt cease to apply to the First Nation land. ${ }^{21}$

A First Nation's laws must be consistent with the land code and in the case of conflict between a First Nation law and the land code, the land code will prevail. ${ }^{22}$ In addition, the power of a First Nation to enact laws for environmental protection are restricted in that the enacted laws and penalties must be at least equivalent to applicable provincial legislation. ${ }^{23}$

The FNLMA provides that a First Nation may create enforcement measures consistent with federal laws, including search and seizure, inspection and the power to order compulsory sampling and production of information..$^{2+}$ Under the FNLMA, First Nations may enact laws that "create offences punishable on summary conviction and provide for the imposition of fines, imprisonment, restitution, community service and any other means for achieving compliance."2s A First Nation may retain its own prosecutors or enter into agreements with federal and provincial governments to use provincial prosecutors. ${ }^{36}$

\section{Case law}

To date, with little judicial interpretation of the FNLMA, there is no substanive case law available on the meaning and effect of the FNLMA generally and its application and effect, in

\author{
Ibid., ss. $18-20$. \\ Ibid. s. $16(1)$. \\ Ibid., s. 19. \\ Ibid. s. 20. \\ Ibid. s. 34(1) \\ Ibid., s. 38. \\ Ihid., s. 20(4) \\ Ibid. s. $21(2)$. \\ Ibid. s. 20(3). \\ lbid., s. 22(1). \\ Jbid., s. 22(3)
}


particular, to third parties. The bulk of the case law referencing the FNLMA deals with its enactment and not necessarily its content. ${ }^{27}$

In B.C. Native Women's Society' $v$. Canada, ${ }^{28}$ the BCNWS challenged the negotiations leading to the Framework Agreement on the basis that Canada had breached the Canadian Charter of Rights and Freedoms ${ }^{20}$ rights of First Nations' women by not including the protection of matrimonial propenty for married Indian women on First Nation land in the Framework Agreement. The Court dismissed the Crown's motion to strike the claim as the portions of the claim concerning the Framework Agreement were not pleadings that could not possibly succeed. The FNLMA has provisions dealing with matrimonial property. ${ }^{30}$

In Chapman v. Canada," a leaseholder on the Musqueam Indian reserve, who had contested a rent increase to the Supreme Court of Canada, ${ }^{32}$ claimed that the Crown, by enacting the FNLMA, breached the leases by delegating the power to expropriate lands, zoning autonomy and other land use powers in a manner not contemplated by the leases. The Court held that the FNLMA would only be enabling. It provides that a land code is a condition precedent to the transfer of powers. Further steps are required before the transfer of powers can be said to cause damage to any leasehold interest. The transfer of powers was, at the stage of the hearings, speculative. It is not possible to establish damages until, and if, the powers that may pass to the Musqueam Band under the FNLMA actually pass.

\section{The, FNLMA and its Potfential. Effect on Tuird Party Interests}

\section{A. EXISTING INTERESTS AND LICHNCES}

The FNLMA attempts to provide express comfort to those existing licences and interests in First Nation land. For example, s. 16(2) of the FNLMA states that "Subject to subsections (3) and (4), interests in and licences in relation to first nation land that exist on the coming into force of a land code continue in accordance with their terms and conditions." Thus, interests and licences in relation to First Nation land subject to a land code continue in accordance with their terms and conditions. However, as s. 16(2) refers, it is subject to s. 16(3), which provides that once a land code comes into effect, the rights and obligations of the Crown as grantor in respect of the interests and licences referenced in s. 16(2) are trans/erred to the First Nation." The effect of s. $16(3)$ is that the Crown no longer has a direct relationship with the third party

However. ss. 34 and 16 of the FWLMA (exemption from liability and continuance of interests in land held pursuant to lirst Nation custom) were briefly considered in Manj. Guns v. Sisiku Nation Tribal Admimistration (2003). 341 A.R. 140 (Prov. Ct.).

3"

:P Part I of the Constituriem Act. 1982, being Scliedule B to the Cancda Act 1982 (U.K.). 1982, c. 11 [Charier].

"II Section 17 of the FNI.MA, supro note 4, requires the First Nation to establisls general rules and procedures in the cases of the breakdown of a marriage. respecting the use, occupation and possession of First Nation land. and the division of interests in that land. [2001]4 C.N.L.R. 70 (B.C.S.C.); sec also Canada (A.G.) W. Weng (2001), 89) B.C.I.R. (3d) 168 (S.C.). Mhusqueam Indian Band v. Cilass, [2000] 2 S.C.R. 633.

Section $16(3)$ of the FNLMA, supra note 4, states: "On the coming into force of the land code of a first nation, the rights and obligations of Iler Majesty as grantor in respect of the interests and licences described in the first nation's individual agreement are trauslerred to the first nation in accordance witls that agreement." 
with respect to interests in and licences in relation to l:irst Nation land, and this relationship changes to one between the First Nation and the third party directly. The First Nation effectively steps into the shoes of the Crown with respect to interests on the reserve lands. Third party interests will then become subject to the land code and any laws enacted by the First Nation. ${ }^{34}$

Any rights held by the Crown in relation to interests or licences in relation to First Nation land that relate to terminating, amending or materially altering the interest of licences or interests are granted to the First Nation. By removing the Crown from the grantor-grantee relationship, the third party loses whatever comfort that may have existed that broader public policy concerns would dictate the use of whatever Crown discretionary authority exists under any given licences or interest in First Nation land. This is not to suggest that First Nations will automatically not consider broader public policy objectives. However, it is fair to assume that the interests of a First Nation will be likely more focused on the needs and desires of that First Nation, rather than on broader public policy objectives such as the provision of rights-of-way for public utilities that may not, in some instances, provide any direct benefit to the First Nation concerned.

The removal of the Crown in the First Nation-third party relationship, by itself, may be a positive step in allowing First Nations to deal directly with their land. The challenge is that First Nations also need to be able to provide the necessary certainty to licences or interests granted in First Nation land. This is where the FNLMA raises concerns.

Also important to note is that the "existing terms and conditions," prior to the FNLMA taking effect, operate in a legal and regulatory environment of federal and provincial laws. As discussed below, First Nations may now impose a new regulatory and legal regime (by way of their law-making authority under the $F N L M A$ ) that may have a dramatic effect on the licences and interests held by third parties on First Nation land, without ever touching the "existing terms and conditions." Thus, while the "existing terms and conditions" may remain intact, additional terms and conditions could be imposed on a third party licence or interest in First Nation land, either directly (where permitted by the licence or interest) or indirectly by imposing new legal or regulatory requirements on the third party. Additionally, it is unclear whether First Nations have the authority to grant full "administration and control" over First Nations lands, such as was formerly granted by the federal Crown over Indian reserve land.

\section{B. EXPROPRIATION}

The FNLMA permits a First Nation to expropriate any interest in First Nation land. If provided in its land code, a First Nation may "expropriate any interest in first nation land that. in the opinion of its council, is necessary for community works or other first nation community purposes." A First Nation is required to pay fair compensation for an expropriated interest in First Nation land and apply the rules set out in the Exyropriation Act. "The key issue is the change of governing authority from the Crown to a first Nation. While with the Crown there 
may be a certain degree of comfort on its willingness, or lack thereof, to use its expropriation authority, it is fair to suggest that the same level of comfort does not exist respecting First Nations, primarily because this authority is so new and because most First Nations do not necessarily have the same public policy objectives as do public governments. The imposition of a requirement of paying fair compensation should place some measure of restraint on the use of such expropriation authority.

The FNLMA provides an important exception to a First Nation's expropriation authority in that interests in land obtained under s. 35 of the Indian Act are expressly exempt from a First Nation's expropriation power. ${ }^{37}$ Section 35 of the Indian Act also provides for expropriation of reserve land, or interest in reserve land, by a province, municipality or local authority, with the consent of the federal government. In short, the s. 35 exception is only helpful to grants existing prior to the application of the FNLMA. However, the question arises as to how a s. 35 interest can be granted under the FNLMA regime, when no express equivalent of section exists within the FNLMA.

Under the FNLMA, only the federal Crown or the First Nation can expropriate land. ${ }^{3 \mathrm{~B}}$ However, Canada's power to expropriate is limited to a federal purpose that serves the national interests and only when no other reasonable alternative for expropriation can be found.$^{39}$ The expropriation by Canada can only be pursued after reasonable efforts have been made to acquire the interest through agreement with the First Nation. ${ }^{40}$ The expropriation must also be limited to the smallest interest, and for only the shortest time necessary. ${ }^{11}$ Public utilities and provincial or municipal governments can no longer expropriate reserve land and Canada cannot expropriate on their behalf.

Interests, other than those granted under $\mathrm{s.} 35$ of the Indian $A c t$, are subject to expropriation by a First Nation acting in accordance with the FNLMA and its land code, with no role for the Crown in such expropriation. While s. 28(2) of the FNLMA protects third party interests held under $\mathrm{s} .35$ of the Indian Act from being expropriated, it does not address the broad array of governance and taxation authority held by First Nations on First Nation land to which such land, and interests and licences in respect of such land, would be subject, as discussed below.

\section{GOVERNANCE AND TAXATION AUTHORITY}

The FNLMA and the land codes flowing therefrom that apply to third parties interests in First Nation land create a new legal and policy regime that displaces the Crown from active decision-making and any substantive role with respect to the granting and management of licences and interests in First Nation land. As noted above, once a land code comes into effect, and subject to the $F N L M A$, a First Nation has the power to grant interests in and licences in relation to First Nation land, manage the natural resources of the land and the power to enact laws respecting interests in and licences in relation to First Nation land and in relation to the 
development, conservation, protection, management, use and possession of such land (including in relation to any matter arising out of or ancillary to such powers). ${ }^{42}$

Additionally, First Nations possess the authority to tax First Nation land or interests in such land for local purposes, and such authority includes taxation relating to rights of third parties to occupy, possess or use First Nation land. ${ }^{43}$ The precise limits of this taxation authority have not yet been thoroughly tested in the courts.

Short of expropriation there are significant taxing, zoning, permitting and regulatory powers that could be brought into play by First Nation governments. There is very little in the way of a corresponding rights to notification or consultation held by third parties on First Nations lands.

The governance and taxation authority held by First Nations under the FNLMA relating to First Nation land is broad and, on its face, serves a positive purpose by enabling First Nations to take greater control over the governance and regulation of their land base. The challenge, however, is for such First Nations to provide the stability and certainty that business entities require before making substantive investments in infrastructure that requires a licence or interest in such First Nation land. The broad First Nation governance and taxation authority, combined with the expropriation powers, raises serious questions and doubts about the certainty of third party interests in respect of First Nation land. This challenge is further exasperated by the drafting of the FNLMA relating to conflict of laws and how the FNLMA relates to other federal laws, as discussed below.

\section{Conflict of Laws}

Another important factor in understanding the effects of the FNLMA on third party interests in First Nation land is to understand the relationship between the FNLMA, First Nation laws made under the FNLMA and the Indian $A c t$ and other federal and provincial laws. Section 37 of the FNLMA states that "In the event of any inconsistency or conflict between this Act and any other federal law, this Act prevails to the extent of the inconsistency or conflict." This paramountcy clause may create confusion and uncertainty as to which laws, federal, First Nation or both, apply in any given circumstance.

The general rule is that where two laws of the same legislative body are inconsistent, the later law repeals the former. ${ }^{44}$ The use of a primacy clause is intended to defeat this doctrine of implied repeal. For example, s. 2 of the Canadian Bill of Rights" states that "[e]very law

Ibid., ss. $18(1), 20(1), 20(2)$ lists more particular law making powers such as laws relating to the regulation, control or prohibition of land use and development, including zoning and subdivision control. the creation, environmental assessment and protection, and the provision of local services and the imposition of "equitable" user charges for those services. Nole the use of the lerm "equitable" rather than "equal." subject to the approval of the Minister of Indian Aftairs, may make by-laws relating to "taxation for local purposes of land, or interests in land, in the reserve, including riglits to occupy, possess or use land in the reserve."

4 Peter Hogg, Constitutional Lav of Canada, 2002 student ed. (Scarborough: Carswell, 2002) at 289.

4s R.S.C. 1960, c. 44 [Bill of Rights]. 
of Canada shall, unless it is expressly declared by an Act of Parliament of Canada that it shall operate notwithstanding the Canadian Bill of Rights, be so construed and applied as not to abrogate, abridge or infringe or to authorise the abrogation, abridgement or infringement of any of the rights or freedoms herein recognised and declared."

In Waskaganish Band v. Blackned, ${ }^{\text {to }}$ the Quebec Provincial Court held that the CreeNaskapi (of Quehec) $\mathrm{ACt},{ }^{47}$ which stipulates that the provisions of the Cree-Naskapi Act take precedence over incompatible provisions of any other federal act, could not prevent the application of the Bill of Rights. The Cree-Naskapi ACt provisions did not meet the requirements for an express declaration stipulated in the Bill of Rights. In $R$. v. Melford Developments, ${ }^{48}$ Melford Developments paid a German bank a fee for its guarantee of a loan made to a chartered Canadian bank. The Minister of National Revenue claimed that this payment was subject to a withholding tax under the Income Tar Act." The respondent objected as the Canada-Germany Income Tax Agreement precluded the application of tax. Section 3 of the Canada-Ciermany Income Tax Agreement ACl, 1956, ${ }^{50}$ stated that "in the event of any inconsistency betiveen the provisions of this Act, or the Agreement, and the operation of any other law, the provisions of this Act and the Agreement prevail to the extent of the inconsistency." The Court held that while Parliament can neither bind itself, nor any successor of Parliament when acting within its constitutionally-assigned sovereign jurisdiction, if it wishes to repeal an act with a paramouncy clause it must do so expressly. The effect of s. 3 is to make the operation of any other law of Parliament subject to the terms of the Act and the Agreement unless Parliament expressly amends the legislation or exempts the later provisions.

Thus, it appears that the FNLMA holds a paranount position among other federal legislation. However, this position is likely not absolute in that other federal legislation dealing with specific matters not contemplated by the FNLMA likely still applies (for example, the National Energy Board Act "). This conclusion is further supported by the Supreme Court of Canada in Multiple Access Lid. v. McCutcheon, ${ }^{52}$ where it held that there will only be conflict or inconsistency between two acts "where one enactment says 'yes' and the other says 'no': 'the same citizens are being told to do inconsistent things'; compliance with one is defiance of the other." The Alberta Court of Appeal in Alberla Power Lid. v. Alberta (Public Utilities Board) stated:

There is no doubt that there exists a presumption of legislative colnerenec; an interprelalion whicli fosters inconsistency or repugnancy belween provisions in different statues is to be avoided.... II is not enough. lhowever, that the two statules deal "somewhat differently" with the same subject inatler; inconsisiency requires that the provisions camnot stand together.

[1986] 3 C.N.I.R. 168 (Qt. I'rov. Ct.)

S.C. 1984. c. 18 [Cree-Naskapi Act]

[1982] 2 S.C.R. 504.

S.C. 1970-71-72. c. 63.

S.C. 1956, c. 33.

R.S.C. 1985, c. N-7.

[1982] 2 S.C.R. 161.

lbid. at 191.

(1990). 102 A.R. 353 at para 31 [emphasis added]. 
The question also arises about whether, in the case of a conflict between a First Nation bylaw enacted under the auspices of the $F N L M A$ or the Framework Agreement, such a bylaw receives the paramountcy benefit of s. 37 of the FNLMA. Section 37 of the FNLMA refers to "this Act" and not a land code or the Framework Agreement. The federal Interpretation Act" defines the term "Act" as meaning an Act of a legislature. Generally, unless expressly stated, an Act ratifying an agreement does not include the agreement. However, courts will first have to turn to standard methods of statutory interpretation in order to determine whether Parliament intended an attachment, schedule or agreement to be included in an Act. In British Columbia (A.G.) v. Canada (A.G.), ${ }^{\text {s6 }}$ the Supreme Court of Canada held that statutory ratification of a scheduled agreement, without more, is not enough to make the agreement a part of the $\mathrm{Act}$. Instead, courts must use the tools of statutory interpretation to determine whether the legislature intended incorporation.

The FNLMA, while having as its main purpose the ratification of the Framework Agreement, simply ratifies and confirms that agreement. Moreover, the FNLMA repeats many important clauses of the Framework Agreement, suggesting that the whole agreement was not intended to have statutory force. The FNLMA states that on certification, a land code has the force of law and judicial notice shall thereafter be taken of it, suggesting binding legal effect and statutory force. Yet there are no provisions in the FNLMA for a land code to become part of the FNLMA.

\section{E. OPTIONS for ThIRD PARTY INTERESTS IN FiRSt NATIONS LANDS}

\section{GOOD BUSINESS REL.ATIONSHIPS WITH HIRST NATIONS}

The FNLMA does not provide for significant third party input into the process of the creation and certification of a land code. ${ }^{37}$ Other than the requirement that a land code have provisions for the publishing of enactments of First Nation laws, there are no specific provisions in the FNLMA for third party input into new First Nation laws passed under it.

As a result, both First Nations and third parties need to be proactive in developing and maintaining good communications and relations with each other so as to assist in developing a good stable business environment. This stable environment can be a critical factor in negotiating successful arrangements between First Nations and third parties respecting licences in and interests relating to First Nation land.

Section 10(4) of the FNLMA, supra note 4, requires that the band council talc approprialt measures to inform third parties who have an interest in land subject 10 a proposed code of both the code and the requisite vote on the code. within a reasonable time before the vote. 


\section{SECTION 35 OF THE INDIAN ACT INTERESTS}

It is not clear the extent to which, or how, a First Nation can, for future grants, grant a s. 35 Indian $A c t$ interest when such interests will likely be granted by a First Nation under the FNLMA and not the Indian Act. However, existing s. 35 interests are protected from expropriation under the FNLMA. Section 35 of the Indian ACt provides that the province, a municipal or local authority or a public utility may, with the consent of the federal Governor in Council, expropriate First Nation land. Once such land has been "unambiguously expropriated"s8 under s. 35, the interest becomes one of fee simple ownership and the First Nation does not retain authority to tax; however, other charges that do not amount to a tax may still be levied, such as regulatory charges or user fees. ${ }^{59}$ The benefits accruing to $\mathrm{s} .35$ interests seem restricted to the protection from expropriation by a First Nation. While limited, this does offer some level of security from expropriation.

\section{AGRLEMENTS WITH FIRST NATIONS}

Absent extensive legislative amendments to the FNLMA, the ability of First Nations to enter into legally binding agreements with third parties in relations to licences in and interests relating to First Nation land appears to be the most sensible and straightforward means of dealing with the ambiguity surrounding security of tenure under the FNLMA regime. Such agreements allow the First Nation to exercise their authority, but in a manner than can ensure additional certainty to third parties, as may be mutually agreed upon. It is important to understand the enforceability of such contracts under the new FNLMA regime.

In Mirchell v. Peguis Indian Band, ${ }^{\infty}$ La Forest J., stated that "[w]hen Indian bands enter the commercial mainstream, it is to be expected that they will have occasion, from time to time, to enter into purely commercial agreements with the provincial Crowns in the same way as with private interests." Justice Wachowich, for the Alberta Court of Queen's Bench in Telecom Leasing Canada (TLC) Limited v. Enoch Indian Band of Stony Plain Indian Reserve No. $135,{ }^{62}$ interpreted this statement to mean that bands have the power to contract and to enter into commercial agreements. The exception would be where that power is expressly limited by the need for Ministerial approval under the Indian Act. Outside those areas specified by the Indian Act, First Nations are free to contract in the same way as any other party, subject to the laws of general application.

The FNLMA expressly states that a First Nation that adopts a land code has the legal capacity necessary to exercise its power and perform its duties and functions under the land code and the FNLMA. Subsection 18(2)(b) of the FNLMA states that a First Nation has the

Osoyoos Indian Band v. Oliver (Town of), [2001] 3 S.C.R. 746; BC Tel v. Seabird Island Indian Band, [2003] ! F.C. 475 (F.C.A.) where there is ambiguity in the expropriating Order in Council about whether the entire interest of the band was being expropriated, since the Crown is bound to impair the Indian interest in the land as little as possible, the Court held that the Order in Council should be interpreted to leave some Indian interest in the land. In the case of Seahird Island, this meant that the band retained some taxing control.

s. Westbank First Nation v. British Columbia Hydro and Power Authorify, [1999] 3 S.C.R. 134.

(a) [1990] 2 S.C.R. 85.

i.) Ibid. at 138.

6. (1992). 133 A.R. 355 
power to enter into contracts, and under s. $18(2)(\mathrm{e})$, be a party to legal proceedings. Subsection 18(4) states that "[a] body established to manage first nation land is a legal entity having the capacity, rights, powers and privileges of a natural person." Further, a corporate entity exercising First Nation powers of land management would be permitted under s. 18(3) of the the FNLMA.

Section 17.7 of the Framework Agreement states that "[a] First Nation is not precluded from entering into an agreement with a utility or public body for the purpose of granting it an interest in First Nation land that is exempt from expropriation by the First Nation." FNLMA does not expressly include a provision allowing for the type of contract contemplated in s. 17.7 of the Framework Agreement. However, it does not expressly disallow such a contract either. However, a third party looking for relief by way of an exemption from expropriation clause would most likely wish that relief to come in the form of an injunction and not necessarily damages. Injunctive relief would provide a security of tenure where damages would not protect third party interests in all cases. While courts have been willing in the past to quash bylaws contradicting previous agreements or contracts, ${ }^{64}$ injunctive relief may be more difficult to achieve under the FNLMA. Under the FNLMA, a First Nation essentially steps into the shoes of the Crown in regard to interests in First Nation land. It is settled law that Parliament cannot bind future Parliaments by contract. ${ }^{\circ 5}$ However, the other contracting party may still have a remedy if the legislative body acts in defiance of a duly approved contract. In Wells $v$. Newfoundland, ${ }^{60} \mathrm{Mr}$. Wells had been appointed to the province's Public Utilities Board on good behaviour until he was 70 . The Legislature later abolished the Board and Mr. Wells' position was eliminated. The Supreme Court of Canada, while agreeing that the Legislature had every right to abolish the Board and Mr. Wclls' position, stated that he still had the right to be compensated for breach of contracl of employment. However, the Legislature could remove the right to be compensated as well, but it would have to be done with clear and specific language. It is unclear if these rights, to legislate out of both contracts and damages, are now possessed by a First Nation under the FNLMA.

It is in this area that a simple amendment to the FNLMA would be of great benefit to First Nations and affected third parties. An amendment to the FNLMA that expressly permits agreements between third parties and First Nations would be definitive respecting the regulatory and legal regime to which the third party interest or licence would be subject.

\section{Conciusion}

Although enacted to provide greater control for First Nations respecting their reserve land base, the FNLMA has created increased uncertainty for third parties seeking access to or interests in First Nation land. If First Nations are to take full advantage of the benefits that the FNLMA may offer, then changes must be made to it so as to create a certain and stable tenure system that will attract and retain investors, industry and other third parties. 
This article has focused on the challenges inherent in the FNLMA regime applicable to third party licences and interests in First Nation land. However, these challenges must be viewed in the content of the FNLMA regime being relatively new and untested, and that many of these challenges may not be borne out in practice, depending on the actions of First Nations under the FNLMA regime. Only time will indicate whether the FNLMA regime will be implemented and utilized by First Nations in a consistent and fair manner so as to ensure certainty of tenure for third party interests in First Nation land. If not, First Nations run the risk of not being able to attract third party interests to invest in or to utilize First Nation land.

To date, little evidence exists indicating that the challenges and possibilities for improving the FNLMA set out in this article will be realized in the near future. The implementation of the FNLMA should be carefully monitored by business, First Nations and the federal and provincial governments to ensure that the resulting regime protects First Nations' interests, but also allows First Nations to grant, with certainty and stability, interests and licences to third parties. 